\title{
Inhibitory Effect of Four Triterpenoids from Trichilia connaroides on Nitric Oxide Production in Lipopolysaccharide-Stimulated RAW264.7 Cells
}

\author{
Hong-Ying Wang, Jun-Song Wang, Yao Zhang, Jun Luo, Ming-Hua Yang, Xiao-Bing Wang, and \\ Ling-Yi Kong*
}

State Key Laboratory of Natural Medicines, Department of Natural Medicinal Chemistry, China Pharmaceutical University; 24 Tong Jia Xiang, Nanjing 210009, People's Republic of China.

Received April 11, 2013; accepted July 24, 2013

Two new highly rearranged trichiliton-type limonoids (trichilitons G-H, 1-2), and two new cycloartane-type triterpenoids, 21-(E)-coumaroyloxy-5 $\alpha$-cycloart-24-ene-3,23-dione (3) and 21-(E)-feruloyloxy-5 $\alpha$ cycloart-24-ene-3,23-dione (4), were isolated from the stem and bark of Trichilia connaroides. These isolates were elucidated on the basis of detailed spectroscopic analysis, and inhibitory effect of these compounds on lipopolysaccharide-induced nitric oxide production in mouse macrophage RAW264.7 cells was evaluated.

Key words Trichilia connaroides; Meliaceae; triterpenoid; nitric oxide production inhibition

Trichilia connaroides (Wight et ARnotT) Bentv (Meliaceae), has been used as folk medicine in China for treatment of arthritis, pharyngitis, tonsillitis, and other ailments. ${ }^{1)}$ Previous chemical investigations on the constituents of $T$. connaroides led to the discovery of many structurally diverse triterpenoids with complex ring systems, ${ }^{2-7)}$ which inspired a continuing interest of this plant. Searching for structurally unique and biologically interesting secondary metabolites, we investigated the dichloromethane extract of the stem and bark of this plant. As a result, two new highly rearranged trichiliton-type limonoids (trichilitons $\mathrm{G}-\mathrm{H}, \mathbf{1}-\mathbf{2}$ ), and two new cycloartane-type triterpenoids, 21- $(E)$-coumaroyloxy-5 $\alpha$ cycloart-24-ene-3,23-dione (3) and 21-(E)-feruloyloxy-5 $\alpha$ cycloart-24-ene-3,23-dione (4) were isolated and identificated. Herein we described the isolation, structure elucidation of these compounds, and their inhibitory effects on lipopolysaccharide-induced nitric oxide production in mouse macrophage

\section{RAW264.7 cells.}

\section{Results and Discussion}

The dichloromethane extract of the stem and bark of $T$. connaroides was chromatographed on MCI, silica gel, and octadecyl silica (ODS) and followed by semi-preparative HPLC to afford four new triterpenoids (1-4) (Fig. 1). The chemical structures of these compounds were determined on the basis of detailed spectroscopic analysis, including high resolutionelectrospray ionization-mass spectrum (HR-ESI-MS), one dimensional (1D)- and 2D-NMR experiments.

Trichiliton G (1) was obtained as a white amorphous powder. Its molecular formula was determined to be $\mathrm{C}_{32} \mathrm{H}_{38} \mathrm{O}_{10}$ by HR-ESI-MS, as indicated by a pseudo-molecular ion at $m / z 581.2399[\mathrm{M}-\mathrm{H}]^{-}$(Calcd for $\mathrm{C}_{32} \mathrm{H}_{37} \mathrm{O}_{10}, 581.2392$ ), suggesting $14^{\circ}$ of unsaturation. The IR spectrum showed strong absorption bands corresponding to functionalities of
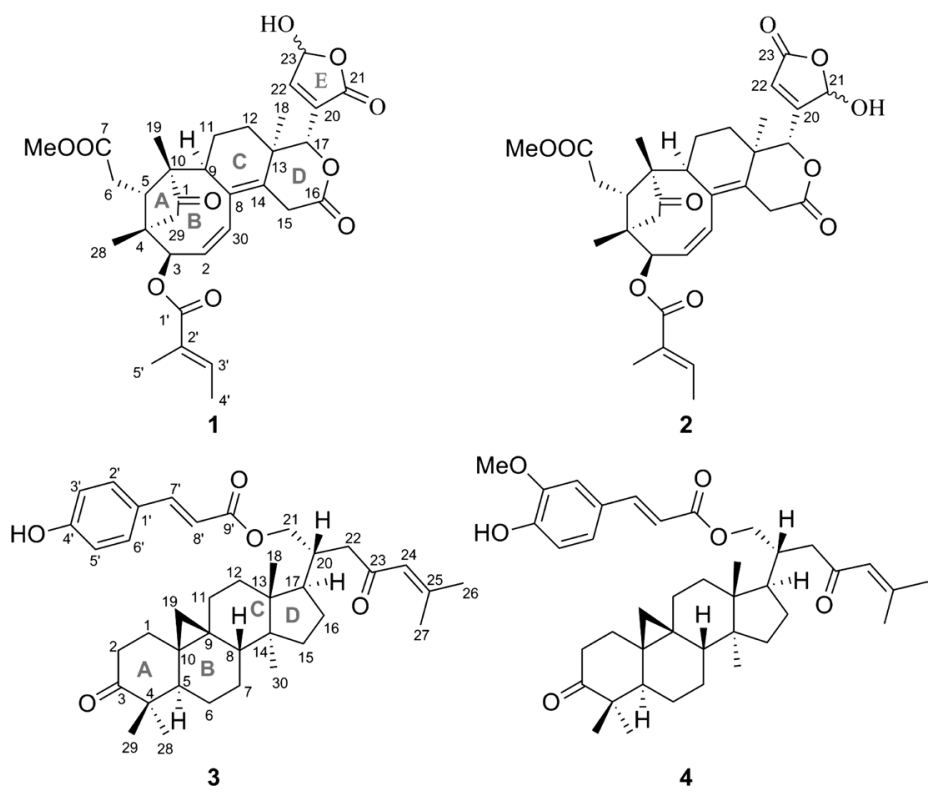

Fig. 1. Structures of Compounds $\mathbf{1}-\mathbf{4}$

The authors declare no conflict of interest. 
Table 1. ${ }^{1} \mathrm{H}(500 \mathrm{MHz})$ and ${ }^{13} \mathrm{C}(125 \mathrm{MHz})$ Data of Compounds 1-4 Measured in $\mathrm{CDCl}_{3}$

\begin{tabular}{|c|c|c|c|c|c|c|c|c|}
\hline \multirow{2}{*}{ Position } & \multicolumn{2}{|c|}{1} & \multicolumn{2}{|c|}{2} & \multicolumn{2}{|c|}{3} & \multicolumn{2}{|c|}{4} \\
\hline & $\delta_{\mathrm{C}}$ & $\delta_{\mathrm{H}}(J$ in $\mathrm{Hz})$ & $\delta_{\mathrm{C}}$ & $\delta_{\mathrm{H}}(J$ in $\mathrm{Hz})$ & $\delta_{\mathrm{C}}$ & $\delta_{\mathrm{H}}(J$ in $\mathrm{Hz})$ & $\delta_{\mathrm{C}}$ & $\delta_{\mathrm{H}}(J$ in $\mathrm{Hz})$ \\
\hline 1a & 221.0 & & 220.0 & & 33.7 & $1.83, \mathrm{~m}$ & 33.7 & $1.83, \mathrm{~m}$ \\
\hline $1 \mathrm{~b}$ & & & & & & $1.52, \mathrm{~m}$ & & $1.51, \mathrm{~m}$ \\
\hline $2 a$ & $135.1 / 135.0$ & $\begin{array}{c}5.84 / 5.88, \mathrm{dd} \\
(12.5,7.5)\end{array}$ & 135.2 & $5.87^{a)}$ & 37.7 & $\begin{array}{c}2.71, \mathrm{td} \\
(13.5,6.0)\end{array}$ & 37.7 & $\begin{array}{c}2.69, \mathrm{td} \\
(14.0,6.5)\end{array}$ \\
\hline $2 \mathrm{~b}$ & & & & & & $\begin{array}{c}2.30, \mathrm{dt} \\
(13.5,3.5)\end{array}$ & & $\begin{array}{l}2.29, \mathrm{dt} \\
(140,4.0)\end{array}$ \\
\hline 3 & 76.9 & $\begin{array}{l}4.82, \mathrm{~d} \\
(7.5)\end{array}$ & 77.3 & $\begin{array}{c}4.81, \mathrm{dd} \\
(5.5,2.5)\end{array}$ & 216.8 & & 216.6 & \\
\hline 4 & 43.6 & & 43.7 & & 50.5 & & 50.5 & \\
\hline 5 & 40.1 & $3.78, \mathrm{~m}$ & 41.2 & $\begin{array}{l}3.71, \mathrm{brd} \\
(13.5)\end{array}$ & 48.7 & $\begin{array}{c}1.70, \mathrm{dd} \\
(12.0,4.0)\end{array}$ & 48.7 & $\begin{array}{c}1.70, \mathrm{dd} \\
(12.0,4.0)\end{array}$ \\
\hline $6 a$ & 34.0 & $2.51, \mathrm{~m}$ & 34.5 & $\begin{array}{c}2.61 / 2.54, \mathrm{dd} \\
(15.5,12.5)\end{array}$ & 21.7 & $1.56, \mathrm{~m}$ & 21.7 & $1.54, \mathrm{~m}$ \\
\hline $6 \mathrm{~b}$ & & $2.35, \mathrm{~m}$ & & $2.41^{a)}$ & & $0.97, \mathrm{~m}$ & & $0.96, \mathrm{~m}$ \\
\hline $7 \mathrm{a}$ & 173.4 & & 176.6 & & 26.1 & $1.38, \mathrm{~m}$ & 26.1 & $1.37, \mathrm{~m}$ \\
\hline $7 \mathrm{~b}$ & & & & & & $1.15, \mathrm{~m}$ & & $1.15, \mathrm{~m}$ \\
\hline 8 & $133.3 / 133.4$ & & 132.5 & & 48.0 & $1.61, \mathrm{~m}$ & 48.1 & $1.61, \mathrm{~m}$ \\
\hline 9 & 44.8 & $\begin{array}{l}2.70, \text { brd } \\
(7.0)\end{array}$ & 44.4 & $\begin{array}{l}2.72, \mathrm{~d} \\
(5.5)\end{array}$ & 21.2 & & 21.2 & \\
\hline 10 & 54.4 & & 54.6 & & 26.3 & & 26.3 & \\
\hline $11 \mathrm{a}$ & 19.5 & $(\alpha) 1.65^{a)}$ & 19.3 & $(\alpha) 1.76, \mathrm{~m}$ & 26.9 & $2.03, \mathrm{~m}$ & 26.9 & $2.02, \mathrm{~m}$ \\
\hline $11 \mathrm{~b}$ & & (B) $1.90, \mathrm{~m}$ & & ( $\beta) 2.00, \mathrm{~m}$ & & $1.19, \mathrm{~m}$ & & $1.19, \mathrm{~m}$ \\
\hline $12 \alpha$ & 28.4 & $1.13, \mathrm{~m}$ & 28.4 & $1.31, \mathrm{~m}$ & 32.0 & $1.63, \mathrm{~m}$ & 32.0 & $1.63, \mathrm{~m}$ \\
\hline $12 \beta$ & & $1.65^{a)}$ & & $1.53, \mathrm{~m}$ & & & & \\
\hline 13 & $38.2 / 38.3$ & & 38.8 & & 45.6 & & 45.6 & \\
\hline 14 & $129.6 / 129.5$ & & 130.7 & & 49.3 & & 49.3 & \\
\hline 15 & 33.1 & $3.13 / 3.11$, brs & 33.0 & $3.10 / 3.13, \mathrm{~s}$ & 35.7 & $1.37^{a)}$ & 35.7 & $1.36^{a)}$ \\
\hline $16 \mathrm{a}$ & 169.1 & & 168.1 & & 28.1 & $1.84, \mathrm{~m}$ & 28.1 & $1.84, \mathrm{~m}$ \\
\hline $16 \mathrm{~b}$ & & & & & & $1.37^{a)}$ & & $1.36^{a)}$ \\
\hline 17 & $79.2 / 79.4$ & $5.32 / 5.36, \mathrm{~s}$ & 80.0 & $5.22, \mathrm{~s}$ & 47.5 & $2.00, \mathrm{~m}$ & 47.5 & $2.00, \mathrm{~m}$ \\
\hline 18 & $16.7 / 16.8$ & $1.06 / 1.03, \mathrm{~s}$ & 16.8 & $1.11, \mathrm{~s}$ & 18.5 & $1.11, \mathrm{~s}$ & 18.6 & $1.12, \mathrm{~s}$ \\
\hline $19 \mathrm{a}$ & 22.9 & $1.00 / 0.99, \mathrm{~s}$ & 23.3 & $1.02 / 1.00, \mathrm{~s}$ & 29.7 & $\begin{array}{l}0.80, \mathrm{~d} \\
(4.0)\end{array}$ & 29.8 & $\begin{array}{l}0.80, \mathrm{~d} \\
(4.0)\end{array}$ \\
\hline $19 b$ & & & & & & $\begin{array}{c}0.57, \mathrm{~d} \\
(4.0)\end{array}$ & & $\begin{array}{c}0.58, \mathrm{~d} \\
(4.0)\end{array}$ \\
\hline 20 & $134.1 / 134.3$ & & 163.1 & & 37.2 & $2.49, \mathrm{~m}$ & 37.2 & $2.50^{a)}$ \\
\hline $21 \mathrm{a}$ & 168.8 & & 97.9 & $6.11, \mathrm{~s}$ & 66.5 & $\begin{array}{c}4.33, \mathrm{dd} \\
(11.5,3.0)\end{array}$ & 66.6 & $\begin{array}{c}4.34, \mathrm{dd} \\
(11.0,2.5)\end{array}$ \\
\hline $21 \mathrm{~b}$ & & & & & & $\begin{array}{c}4.02, \mathrm{dd} \\
(11.5,6.5)\end{array}$ & & $\begin{array}{c}4.03, \mathrm{dd} \\
(11.0,7.0)\end{array}$ \\
\hline 22 & $150.0 / 150.2$ & $7.35 / 7.36, \mathrm{~s}$ & 122.2 & $6.28, \mathrm{~s}$ & 46.7 & $2.50, \mathrm{~m}$ & 46.7 & $2.50^{a)}$ \\
\hline 23 & $96.8 / 97.2$ & $6.19 / 6.22, \mathrm{~s}$ & 169.5 & & 200.5 & & 200.3 & \\
\hline 24 & & & & & 124.5 & 6.06, brs & 124.5 & 6.06, brs \\
\hline 25 & & & & & 155.5 & & 155.4 & \\
\hline 26 & & & & & 27.9 & $1.85, \mathrm{~s}$ & 27.9 & $1.84, \mathrm{~s}$ \\
\hline 27 & & & & & 21.04 & $2.13, \mathrm{~s}$ & 21.02 & $2.13, \mathrm{~s}$ \\
\hline 28 & 22.6 & $1.13, \mathrm{~s}$ & 23.1 & $1.15 / 1.14, \mathrm{~s}$ & 22.4 & $1.04, \mathrm{~s}$ & 22.4 & $1.04, \mathrm{~s}$ \\
\hline $29 \mathrm{a}$ & 47.0 & $\begin{array}{l}2.05, \mathrm{~d} \\
(17.5)\end{array}$ & 46.6 & $\begin{array}{c}2.11 / 2.09, \mathrm{~d} \\
\quad(17.5)\end{array}$ & 21.0 & $1.10, \mathrm{~s}$ & 21.0 & $1.10, \mathrm{~s}$ \\
\hline $29 \mathrm{~b}$ & & $\begin{array}{l}2.45, \mathrm{~d} \\
(17.5)\end{array}$ & & $\begin{array}{l}2.41, \mathrm{~d} \\
(17.5)\end{array}$ & & & & \\
\hline 30 & $129.9 / 129.8$ & $\begin{array}{c}5.85 / 5.87, \mathrm{~d} \\
\quad(12.5)\end{array}$ & 129.8 & $5.87^{a)}$ & 19.6 & $0.93, \mathrm{~s}$ & 19.7 & $0.93, \mathrm{~s}$ \\
\hline $\mathrm{OMe}$ & 52.1 & $3.68 / 3.69, \mathrm{~s}$ & 52.9 & $3.76 / 3.72, \mathrm{~s}$ & & & 56.3 & $3.93, \mathrm{~s}$ \\
\hline $1^{\prime}$ & 167.5 & & 167.2 & & 127.5 & & 127.3 & \\
\hline $2^{\prime}$ & 128.5 & & 128.7 & & 130.2 & $\begin{array}{l}7.39, \mathrm{~d} \\
(8.5)\end{array}$ & 109.7 & $\begin{array}{l}7.01, \mathrm{~d} \\
(2.0)\end{array}$ \\
\hline $3^{\prime}$ & 139.7 & $\begin{array}{l}7.34, \mathrm{q} \\
(7.0)\end{array}$ & 139.3 & $\begin{array}{l}7.07, \mathrm{q} \\
(7.0)\end{array}$ & 116.2 & $\begin{array}{c}6,84, \mathrm{~d} \\
(8.5)\end{array}$ & 147.1 & \\
\hline
\end{tabular}


Table 1. Continued

\begin{tabular}{|c|c|c|c|c|c|c|c|c|}
\hline \multirow{2}{*}{ Position } & \multicolumn{2}{|c|}{1} & \multicolumn{2}{|c|}{2} & \multicolumn{2}{|c|}{3} & \multicolumn{2}{|c|}{4} \\
\hline & $\delta_{\mathrm{C}}$ & $\delta_{\mathrm{H}}(J$ in $\mathrm{Hz})$ & $\delta_{\mathrm{C}}$ & $\delta_{\mathrm{H}}(J$ in $\mathrm{Hz})$ & $\delta_{\mathrm{C}}$ & $\delta_{\mathrm{H}}(J$ in $\mathrm{Hz})$ & $\delta_{\mathrm{C}}$ & $\delta_{\mathrm{H}}(J$ in $\mathrm{Hz})$ \\
\hline $4^{\prime}$ & 14.7 & $\begin{array}{c}1.76, \mathrm{~d} \\
(7.0)\end{array}$ & 14.6 & $\begin{array}{c}1.76, \mathrm{~d} \\
(7.0)\end{array}$ & 158.1 & & 148.2 & \\
\hline $5^{\prime}$ & 12.3 & $1.79, \mathrm{~s}$ & 12.4 & $1.77, \mathrm{~s}$ & 116.2 & $\begin{array}{c}6.84, \mathrm{~d} \\
(8.5)\end{array}$ & 115.0 & $\begin{array}{c}6.91, \mathrm{~d} \\
(8.0)\end{array}$ \\
\hline $6^{\prime}$ & & & & & 130.2 & $\begin{array}{l}7.39, \mathrm{~d} \\
(8.5)\end{array}$ & 123.3 & $\begin{array}{c}7.05, \mathrm{dd} \\
(8.0,2.0)\end{array}$ \\
\hline $7^{\prime}$ & & & & & 144.5 & $\begin{array}{l}7.56, \mathrm{~d} \\
(16.0)\end{array}$ & 145.0 & $\begin{array}{l}7.55, \mathrm{~d} \\
(16.0)\end{array}$ \\
\hline $8^{\prime}$ & & & & & 115.8 & $\begin{array}{c}6.22, \mathrm{~d} \\
(16.0)\end{array}$ & 115.8 & $\begin{array}{c}6.22, \mathrm{~d} \\
(16.0)\end{array}$ \\
\hline $9^{\prime}$ & & & & & 167.5 & & 167.5 & \\
\hline
\end{tabular}

a) Overlapped with other signals.

hydroxyl $\left(3450 \mathrm{~cm}^{-1}\right)$, carbonyl $\left(1735 \mathrm{~cm}^{-1}\right)$ and double bond $\left(1641 \mathrm{~cm}^{-1}\right)$. Apart from the easily distinguishable signals for a methoxyl $\left[\delta_{\mathrm{H}} 3.68 / 3.69(3 \mathrm{H}, \mathrm{s})\right]$, and a tigloyl group $\left[\delta_{\mathrm{H}} 1.76\right.$ $(3 \mathrm{H}, \mathrm{d}, J=7.0 \mathrm{~Hz}), 1.79(3 \mathrm{H}, \mathrm{s})$, and $7.34(1 \mathrm{H}, \mathrm{q}, J=7.0 \mathrm{~Hz})]$, the ${ }^{1} \mathrm{H}-\mathrm{NMR}$ spectrum of $\mathbf{1}$ (Table 1) also presented three singlet methyl protons at $\delta_{\mathrm{H}} 1.06 / 1.03,1.00 / 0.99$ and 1.13. Its ${ }^{13} \mathrm{C}-\mathrm{NMR}$ spectrum (Table 1 ) resolved 32 carbon resonances, after deduction of the carbons belonging to the methoxyl and the tigloyl group, 26 carbons remained in the skeleton, suggesting a tetranortriterpenoid nature of $\mathbf{1}$. Nine degrees of unsaturation were accounted by four double bonds, four ester carbonyls, and one ketone carbonyl, the remaining five degrees of unsaturation requiring five rings for compound $\mathbf{1}$. The signals for a typical lactone ring $\mathrm{D}$ was observed in the NMR spectrum, characterized by the following NMR data $\left[\delta_{\mathrm{H}}\right.$ $3.13 / 3.11\left(2 \mathrm{H}\right.$, br s), 5.32/5.36 $(1 \mathrm{H}, \mathrm{s}) ; \delta_{\mathrm{C}} 38.2 / 38.3,129.6 / 129.5$, $33.1,169.1,79.2 / 79.4]$. Its presence was also evidenced by the heteronuclear multiple bond connectivity (HMBC) correlations (Fig. 2) of $\mathrm{H}_{2}-15 / \mathrm{C}-14, \mathrm{H}_{2}-15 / \mathrm{C}-16, \mathrm{H}_{2}-15 / \mathrm{C}-13$ and $\mathrm{H}-17 / \mathrm{C}-13$. A carbon signal at $\delta_{\mathrm{C}} 47.0$ corresponded in the heteronuclear single quantum coherence (HSQC) spectrum to a pair of geminal doublets at $\delta_{\mathrm{H}} 2.05$ and 2.45, which had the HMBC correlations with ketone carbonyl C-1, C-4, C-10, C-5 and C-28, was assigned to $\mathrm{C}-29$. In the $\mathrm{HMBC}$ spectrum, correlations from a multiplet at $\delta_{\mathrm{H}} 3.78(\mathrm{H}-5)$ to $\mathrm{C}-6, \mathrm{C}-10, \mathrm{C}-1$ and $\mathrm{C}-4$, and from a singlet methyl proton at $\delta_{\mathrm{H}} 1.00 / 0.99$ (Me-19) to C-10, C-5 and C-1, suggested the construction of a cyclopentanone ring A by C-1, C-29, C-4, C-5, and C-10, characteristic of a trichiliton-type limonoids. Detailed analysis of its NMR data revealed that it was structurally similar to chisomicine $\mathrm{A},{ }^{8)}$ except for ring $\mathrm{E}$ : the $\beta$-furanyl ring in chisomicine $\mathrm{A}$ was replaced by a $\gamma$-hydroxybutenolide group, ${ }^{9,10)}$ characterized by a pair of protons at $\delta_{\mathrm{H}} 7.35 / 7.36(\mathrm{H}-22)$ and $6.19 / 6.22$ $(\mathrm{H}-23)$, and carbon resonances in pair at $\delta_{\mathrm{C}} 134.1 / 134.3(\mathrm{C}-20)$, 168.8 (C-21), 150.0/150.2 (C-22), and 96.8/97.2 (C-23). HMBC cross-peaks from $\mathrm{H}-17$ to $\mathrm{C}-20, \mathrm{C}-21$ and $\mathrm{C}-22$, located the $\gamma$-hydroxybutenolide group at $\mathrm{C}-17$; the strong $\mathrm{HMBC}$ correlation between the proton at $\delta_{\mathrm{H}} 4.82(\mathrm{H}-3)$ and the carbonyl carbon of the tigloyl group at $\delta_{\mathrm{C}} 167.5$ allowed its position at C-3. Thus, the planar structure of $\mathbf{1}$ was established. The relative configuration of $\mathbf{1}$ was determined by the rotating frame Overhauser effect correlation spectroscopy (ROESY) experiment. As shown in Fig. 2, the observed correlations of Me-28/H-5, H-5/H-17, H-17/H-12 $\beta$, and H-5/Me-19 revealed

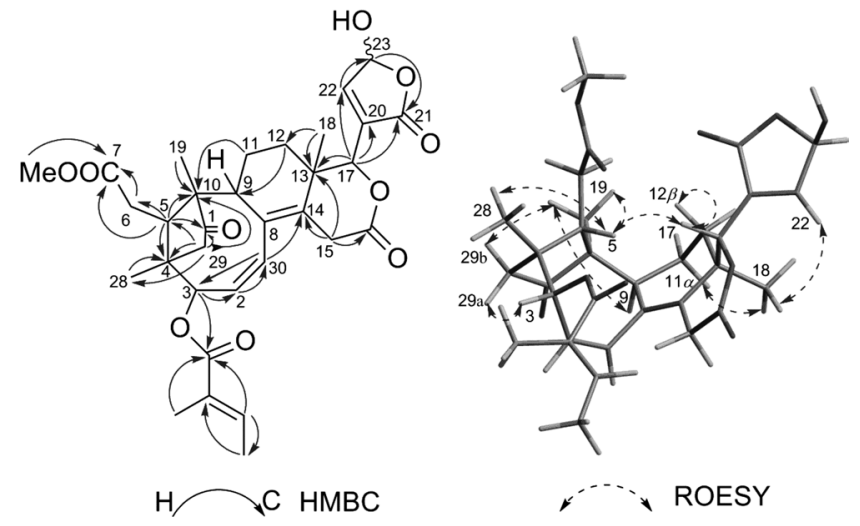

Fig. 2. Key HMBC and ROESY Correlations of $\mathbf{1}$

that H-5, H-17, Me-19, and Me-28 were cofacial and thus were arbitrarily assigned to be $\beta$-oriented. The assignment of Me- 18 as $\alpha$-orientation was deduced from the ROESY correlations of $\mathrm{Me}-18 / \mathrm{H}-22$ and Me-18/H-11 $\alpha$. The correlations of $\mathrm{H}-3 / \mathrm{H}-29 \mathrm{a}$, Me-19/H-29b, and Me-19/H-9 indicated that H-3, H-9, and $\mathrm{H}_{2}-29$ were $\alpha$-oriented. The relative configurations of all the chiral centers of $\mathbf{1}$ are in agreement with trichiliton A obtain from this plant. ${ }^{2)}$ The molecule adopt a cage-like conformation, and the lactone ring $\mathrm{D}$ is in a half-chair conformation. Thus, the structure of $\mathbf{1}$ was established as trichiliton G.

Compound 2 had the same molecular formula of $\mathrm{C}_{32} \mathrm{H}_{38} \mathrm{O}_{10}$ as that of $\mathbf{1}$. The NMR spectroscopic data (Table 1) of $\mathbf{1}$ and 2 suggested a great structure resemblance of them except for ring E. The NMR spectroscopic data of $\mathbf{2}$ suggested the presence of a 21-hydroxybutenolide ring $\mathrm{E}$ characterized by protons at $\delta_{\mathrm{H}} 6.28(\mathrm{H}-22)$ and $6.11(\mathrm{H}-21)$, and by carbon resonances at $\delta_{\mathrm{C}} 163.1(\mathrm{C}-20), 97.9(\mathrm{C}-21), 122.2$ (C-22), and 169.5 (C-23), which was confirmed by the HMBC correlation between $\mathrm{H}-17$ and the hemiacetal carbon $(\mathrm{C}-21) .{ }^{10,11)}$ The relative configuration of $\mathbf{2}$ was elucidated to be the same as that $\mathbf{1}$. The structure of 2 was thus established as trichiliton $\mathrm{H}$.

21-(E)-Coumaroyloxy-5 $\alpha$-cycloart-24-ene-3,23-dione was obtained as white amorphous powder and its molecular formula was deduced to be $\mathrm{C}_{39} \mathrm{H}_{52} \mathrm{O}_{5}$ with $14^{\circ}$ of unsaturation on the basis of its HR-ESI-MS positive-ion at $\mathrm{m} / \mathrm{z}$ 623.3705 $[\mathrm{M}+\mathrm{Na}]^{+}$(Calcd for $\mathrm{C}_{39} \mathrm{H}_{52} \mathrm{O}_{5} \mathrm{Na}, 623.3707$ ). Its IR spectrum showed strong absorption bands corresponding to functionalities of hydroxyl $\left(3423 \mathrm{~cm}^{-1}\right)$, carbonyl $\left(1704 \mathrm{~cm}^{-1}\right)$, and olefinic groups $\left(1628 \mathrm{~cm}^{-1}\right)$. An $\mathrm{A}_{2} \mathrm{X}_{2}$ coupling system 


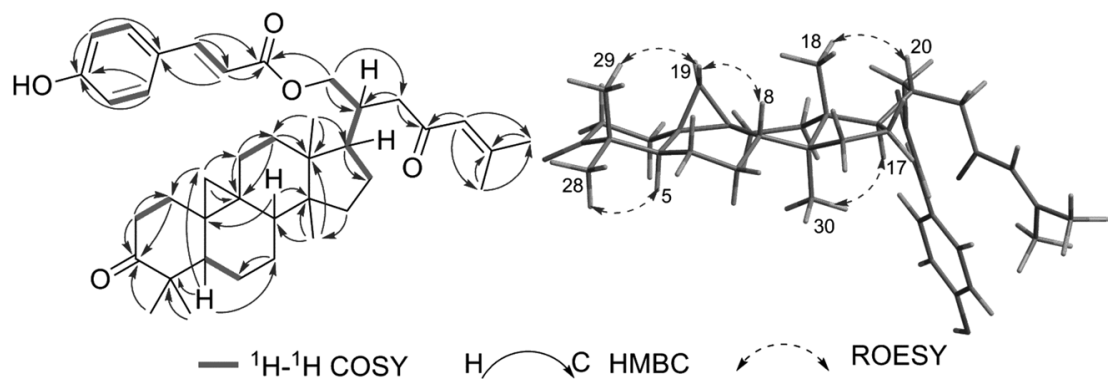

Fig. 3. ${ }^{1} \mathrm{H}-{ }^{1} \mathrm{H}$ COSY, Key HMBC and ROESY Correlations of $\mathbf{3}$

existed through the signals at $\delta_{\mathrm{H}} 7.39$ and $6.84(\mathrm{~d}, J=8.5 \mathrm{~Hz})$ and an AX-type signals at $\delta_{\mathrm{H}} 7.56$ and $6.22(\mathrm{~d}, J=16.0 \mathrm{~Hz})$ in its ${ }^{1} \mathrm{H}-\mathrm{NMR}$ spectrum (Table 1), indicated the presence of (E)-coumaroyl group. ${ }^{12)}$ Furthermore, the ${ }^{1} \mathrm{H}-\mathrm{NMR}$ spectrum also showed the presence of a broad singlet of an olefinic methine at $\delta_{\mathrm{H}} 6.06$, four tertiary methyl singlets at $\delta_{\mathrm{H}} 0.93$, $1.10,1.11$, and 1.04 in the up-field region, two geminal vinylmethyls at $\delta_{\mathrm{H}} 1.85$ and 2.13 , as well as C-9/C-10 cyclopropyl methylene, featuring a pair of geminal protons at $\delta_{\mathrm{H}} 0.80$ and $0.57(\mathrm{~d}, J=4.0 \mathrm{~Hz})$ in the up-field region. Except for the nine carbons belonging to the $(E)$-coumaroyl moiety, the remaining 30 carbons in the ${ }^{13} \mathrm{C}$-NMR spectrum, suggested $\mathbf{3}$ to be a normal cycloartane-type triterpene. ${ }^{13)}$ Aided with the HSQC spectrum, these carbons were categoried into 6 tertiary methyls, 11 methylenes (one oxymethylene at $\delta_{\mathrm{C}} 66.5$ ), 5 methines (one olefinic carbon at $\delta_{\mathrm{C}} 124.5$ ), and 8 quaternary carbons (two ketone at $\delta_{\mathrm{C}} 216.5$ and 200.5, and one olefinic carbon at $\left.\delta_{\mathrm{C}} 155.5\right)$. The HMBC correlations from a ketone carbonyl carbon at $\delta_{\mathrm{C}} 216.5$ to $\mathrm{H}_{2}-2\left(\delta_{\mathrm{H}} 2.71\right.$ and 2.30$)$, Me-28 $\left(\delta_{\mathrm{H}} 1.04\right)$ and Me-29 $\left(\delta_{\mathrm{H}} 1.10\right)$, located the ketone group at C-3. In the HMBC spectrum, correlations from an olefinic proton at $\delta_{\mathrm{H}}$ 6.06 to two geminal vinylmethyls C-26 $\left(\delta_{\mathrm{C}} 27.9\right)$ and C-27 $\left(\delta_{\mathrm{C}}\right.$ $21.04)$, and a ketone carbonyl carbon at $\delta_{\mathrm{C}} 200.5$, indicated that 3 possessed a $\Delta^{24,25}$ double bond, and the ketone carbonyl carbon was assigned to be $\mathrm{C}-23$, which was also evidenced by the HMBC correlation from $\mathrm{H}_{2}-22\left(\delta_{\mathrm{H}} 2.50\right)$ to this ketone carbonyl carbon. HMBC cross-peaks from a pair of oxymethylene protons at $\delta_{\mathrm{H}} 4.33(\mathrm{dd}, J=11.5,3.0 \mathrm{~Hz})$ and $4.02(\mathrm{dd}$, $J=11.5,6.5 \mathrm{~Hz})$ to the carbonyl carbon of the $(E)$-coumaroyl moiety C-9' $\left(\delta_{\mathrm{C}} 167.5\right), \mathrm{C}-20\left(\delta_{\mathrm{C}} 37.2\right)$, and C-22 $\left(\delta_{\mathrm{C}} 46.7\right)$, and ${ }^{1} \mathrm{H}-{ }^{1} \mathrm{H}$ correlation spectroscopy (COSY) correlation between these two oxymethylene protons with $\mathrm{H}-20\left(\delta_{\mathrm{H}} 2.49\right)$, attached the $(E)$-coumaroyloxy moiety to $\mathrm{C}-21$. The full assignment and connectivity of protons and carbons in the structure were made by 2D-NMR experiments (Fig. 3). Therefore, the planar structure of $\mathbf{3}$ was established as shown.

The relative configuration of $\mathbf{3}$ was determined on the basis of ROESY spectrum (Fig. 3). The significant cross-peaks from Me-29 to H-19a and H-19b, and from H-19a to H-8, suggested that $\mathrm{H}-8, \mathrm{H}_{2}-19$, and Me-29 were co-facial and were arbitrarily assigned to be in $\beta$-orientation; correlations of $\mathrm{H}-5 / \mathrm{Me}-28$, and $\mathrm{H}-17 / \mathrm{Me}-30$ revealed an $\alpha$-orientation for these protons. According to biosynthetic origin, Me-18 of cycloartane-type triterpenes was constantly in $\beta$-orientation. ${ }^{13-16)}$ The NOE associations via a ROESY spectrum from ring to side chain protons could lead to erroneous configurational conclusions. Generally, H-17 and H-20 are biosynthetically in trans configuration for cycloartane-type triterpenes: $\mathrm{H}-17$ was assigned to be $\alpha$-orientated according to the ROESY correlation of H-17/
Me-30, H-20 was thus in $\beta$-orientation accordingly, consistent with those reported in the literature. ${ }^{13-16)}$ Therefore, the structure of $\mathbf{3}$ is established as 21-(E)-coumaroyloxy-5 $\alpha$-cycloart24-ene-3,23-dione.

21-(E)-Feruloyloxy-5 $\alpha$-cycloart-24-ene-3,23-dione (4) had a molecular formula of $\mathrm{C}_{40} \mathrm{H}_{54} \mathrm{O}_{6}$, as determined by the observed pseudo-molecular ion at $631.3992[\mathrm{M}+\mathrm{H}]^{+}$(Calcd for $\left.\mathrm{C}_{40} \mathrm{H}_{55} \mathrm{O}_{6}, 631.3993\right)$ in the HR-ESI-MS, 30 units more than that of 3. Its NMR data exhibited a pair of doublets typical for cyclopropane methylene protons at $\delta_{\mathrm{H}} 0.80$ and 0.58 , a broad singlet olefinic methine at $\delta_{\mathrm{H}} 6.06$, four tertiary methyl singlets at $\delta_{\mathrm{H}} 0.93,1.10,1.12$, and 1.04 , and two geminal vinylmethyls at $\delta_{\mathrm{H}} 1.85$ and 2.13, suggesting 4 to be also a cycloartane-type triterpenoid like 3 . The great resemblance of their 1D-NMR data, especially those associated with rings A-D and the side chain combined with the 2D-NMR data revealed that they share the same carbon skeleton. The major difference was the appearance of an $(E)$-feruloyl moiety in $\mathbf{4}$ rather than a $(E)$-coumaroyl moiety at $\mathrm{C}-21$ in $\mathbf{3}$, as supported by an AMX-type signals at $\delta_{\mathrm{H}} 7.01(\mathrm{~d}, J=2.0 \mathrm{~Hz}), 7.05(\mathrm{dd}$, $J=8.0,2.0 \mathrm{~Hz})$, and $6.91(\mathrm{~d}, J=8.0 \mathrm{~Hz})$, ascribed to a $1,3,4$-trisubstituted aromatic ring, an AX-type signals at $\delta_{\mathrm{H}} 7.55$ and $6.22(\mathrm{~d}, J=16.0 \mathrm{~Hz})$, and oxygenated methyl protons at $\delta_{\mathrm{H}}$ $3.93 .^{17)}$ The similar ROESY correlations of $\mathbf{4}$ and $\mathbf{3}$ indicated the same relative configurations of them. Thus, the structure of 4 is established as 21-(E)-feruloyloxy-5 $\alpha$-cycloart-24-ene3,23-dione.

Four isolates were evaluated for their inhibitory effects of nitric oxide (NO) production stimulated by lipopolysaccharide (LPS) in RAW264.7 cells using $N$-monomethyl-L-arginine as the reference compound with $\mathrm{IC}_{50}$ value at $37.7 \mu \mathrm{m}$. To avoid any false-positive results caused by the cytotoxicity of the tested samples, the effects of the four triterpenoids on the growth of RAW264.7 cells were assessed by 3-(4,5-dimethylthiazol-2-yl)-2,5-diphenyltetrazolium bromide (MTT) assay before evaluating their nitric oxide production inhibitory activity. None of them showed any effect on cell growth with a concentration up to $100 \mu \mathrm{M}$. Among them, compounds 1 and 2 expressed moderate $\mathrm{NO}$ inhibition with $\mathrm{IC}_{50}$ values of 46.5 and $62.1 \mu \mathrm{m}$, respectively, which revealed that the trichiliton framework seem to produce a positive effect on the activity. The data were in agreement with those of previously found for analogous compounds. ${ }^{8)}$ The other two compounds, both with $\mathrm{IC}_{50}$ values over $100 \mu \mathrm{M}$, were regarded as inactive.

\section{Experimental}

General Experimental Procedures Optical rotations were determined with a JASCO P-1020 polarimeter. UV spectra were measured on a Shimadzu UV-2450 spectropo- 
larimeter. IR spectra were obtained on a Bruker Tensor 27 spectrometer ( $\mathrm{KBr}$ discs). NMR spectra were recorded on Bruker ACF-500 instrument $\left({ }^{1} \mathrm{H}: 500 \mathrm{MHz},{ }^{13} \mathrm{C}: 125 \mathrm{MHz}\right)$, with tetramethylsilane (TMS) as internal standard. Chemical shifts were given in values of ppm and coupling constants in Hertz. High-resolution mass spectra were recorded on an Agilent UPLC-Q-TOF (6520B). Analytical HPLC was performed on Agilent 1100 series (Agilent, Santa Clara, CA, U.S.A.) with SB- $\mathrm{C}_{18}$ column $(4.6 \times 250 \mathrm{~mm}, 5 \mu \mathrm{m})$. Semi-preparative HPLC was carried out using a Shimadzu SCL-10A Series instrument with a Capcell-park RP-C ${ }_{18}$ column $(10 \times 250 \mathrm{~mm}, 5 \mu \mathrm{m})$ and a SPD 6A variable wavelength detector. All solvents used were of analytical grade (Jiangsu Hanbang Science and Technology. Co., Ltd.). Silica gel (Qingdao Haiyang Chemical Co., Ltd.), Sephadex LH-20 (Pharmacia), MCI gel (75-150 $\mu \mathrm{m}$, Mitsubishi) and $\mathrm{RP}^{-\mathrm{C}_{18}}(40-63 \mu \mathrm{m}, \mathrm{Fuji})$ were used for column chromatography (CC). The pre-coated silica gel $\mathrm{GF}_{254}$ plates (Qingdao Marine Chemical Plant, Qingdao, China) were used for TLC. Spots were visualized by heating silica gel plates immersed in $10 \% \mathrm{H}_{2} \mathrm{SO}_{4}$ in ethanol.

Plant Material The stem and bark of $T$. connaroides (W. et A.) Bentv were collected from Xishuangbanna, Yunnan Province, China, in November 2011 and authenticated by Prof. Shun-Cheng Zhang of Xishuangbanna Botanical Garden, Chinese Academy of Sciences. A voucher specimen (No. ZGH-201111) has been deposited in the Department of Natural Medicinal Chemistry, China Pharmaceutical University.

Extraction and Isolation The air-dried stem and bark of T. connaroides $(10 \mathrm{~kg})$ were extracted with $95 \% \mathrm{EtOH}$ for $2 \mathrm{~h}$ three times under reflux and concentrated to give the extracts. The extracts $(1280 \mathrm{~g})$ were suspended in $\mathrm{H}_{2} \mathrm{O}$ and partitioned with petroleum ether (PE), dichloromethane $\left(\mathrm{CH}_{2} \mathrm{Cl}_{2}\right)$, and ethyl acetate (EtOAc), respectively. The $\mathrm{CH}_{2} \mathrm{Cl}_{2}(64.0 \mathrm{~g})$ extract was subjected to silica gel column and eluted with $\mathrm{PE}-$ EtOAc in a gradient $(1: 0$ to $0: 1, \mathrm{v} / \mathrm{v})$ to give seven fractions (Frs. 1-7).

Fraction 4 (12.4g) was chromatographed on MCI gel eluted successively with $\mathrm{MeOH}-\mathrm{H}_{2} \mathrm{O}(2: 8$ to $9: 1, \mathrm{v} / \mathrm{v})$, to give four subfractions (Frs. 4a-d). Fraction $4 \mathrm{~b}(4.0 \mathrm{~g})$ was subjected to columns of silica gel, eluted with $\mathrm{CH}_{2} \mathrm{Cl}_{2}-\mathrm{MeOH}(100: 1$ to $5: 1, \mathrm{v} / \mathrm{v})$, five subfractions $4 \mathrm{~b}-1$ to $4 \mathrm{~b}-5$ obtained. Subfractions $4 b-3 a$ to $4 b-3 d$ was given by separated the fraction $4 b-3$ $(340.0 \mathrm{mg})$ with reversed-phase $\mathrm{ODS}\left(\mathrm{MeOH}-\mathrm{H}_{2} \mathrm{O} ; 5: 5\right.$ to $9: 1, \mathrm{v} / \mathrm{v})$. Fraction 4b-3b (12.0 mg) was further purified by successive RP-18 semi-preparative HPLC by elution with $83 \%$ acetonitrile in water. $(10 \mathrm{~mL} / \mathrm{min})$, to afford $3(4.0 \mathrm{mg}$, $\left.t_{\mathrm{R}}=74.5 \mathrm{~min}\right)$ and $4\left(5.0 \mathrm{mg}, t_{\mathrm{R}}=84.0 \mathrm{~min}\right)$.

Fraction $6(8.2 \mathrm{~g})$ was subjected to column of MCI gel for removing chlorophyll eluted successively with $\mathrm{MeOH}-\mathrm{H}_{2} \mathrm{O}$ $(2: 8$ to $9: 1, \mathrm{v} / \mathrm{v})$, to provide three major subfractions (Frs. $6 \mathrm{a}-\mathrm{c})$. Then fraction $6 \mathrm{~b}(4.5 \mathrm{~g})$ was fractioned by silica gel column chromatography, eluted with $\mathrm{CH}_{2} \mathrm{Cl}_{2}-\mathrm{MeOH}(100: 1$ to $5: 1, \mathrm{v} / \mathrm{v}$ ), to give five subfractions (Frs. 6b-1 to 6b-5), and fraction $6 \mathrm{~b}-1$ (1.9g) was further separated by silica gel column chromatography (petroleum ether-acetone; 10:1 to $1: 4, v / v)$, to yield five subfractions $6 \mathrm{~b}-1 \mathrm{a}$ to $6 \mathrm{~b}-1 \mathrm{e}$. Fraction $6 \mathrm{~b}-1 \mathrm{~b}(760.0 \mathrm{mg})$ was chromatographed over successive reversed-phase ODS with $\mathrm{MeOH}-\mathrm{H}_{2} \mathrm{O}$ (3:7 to $\left.8: 2, \mathrm{v} / \mathrm{v}\right)$, to yield seven subfractions, and the fifth fraction $(83.5 \mathrm{mg})$ eluted with $45 \%$ acetonitrile in water $(10 \mathrm{~mL} / \mathrm{min})$ to give $1(12.0 \mathrm{mg}$, $\left.t_{\mathrm{R}}=33.4 \mathrm{~min}\right)$, and $2\left(14.5 \mathrm{mg}, t_{\mathrm{R}}=39.3 \mathrm{~min}\right)$.
Trichiliton G (1): White, amorphous powder; $[\alpha]_{\mathrm{D}}^{25}-2.3$ $(c=0.26, \mathrm{MeCN}) ; \mathrm{UV}(\mathrm{MeCN}) \lambda_{\max }(\log \varepsilon) 196$ (4.37), 280 (3.03) nm; IR (KBr) $v_{\max } 3450,2921,2850,1735,1641,1400$, 1273, 1198, $1016 \mathrm{~cm}^{-1}$; ${ }^{1} \mathrm{H}$ - and ${ }^{13} \mathrm{C}-\mathrm{NMR}$ data, see Table 1; HR-ESI-MS $m / z 581.2399[\mathrm{M}-\mathrm{H}]^{-}$(Calcd for $\mathrm{C}_{32} \mathrm{H}_{37} \mathrm{O}_{10}$, 581.2392).

Trichiliton $\mathrm{H}$ (2): White, amorphous powder; $[\alpha]_{\mathrm{D}}^{25}-11.9$ $(c=0.12, \mathrm{MeCN}) ; \mathrm{UV}(\mathrm{MeCN}) \lambda_{\max }(\log \varepsilon) 198$ (4.39), 281 (2.19) nm; IR (KBr) $v_{\max } 3450,2919,2850,1736,1640,1400$, 1274, 1136, $1033 \mathrm{~cm}^{-1}$; ${ }^{1} \mathrm{H}-$ and ${ }^{13} \mathrm{C}-\mathrm{NMR}$ data, see Table 1; HR-ESI-MS m/z 581.2386 [M-H] ${ }^{-}$(Calcd for $\mathrm{C}_{32} \mathrm{H}_{37} \mathrm{O}_{10}$, 581.2392).

21-(E)-Coumaroyloxy-5 $\alpha$-cycloart-24-ene-3,23-dione White, amorphous powder; $[\alpha]_{\mathrm{D}}^{25}+43.9(c=0.13, \mathrm{MeCN})$; UV $(\mathrm{MeCN}) \lambda_{\max }(\log \varepsilon) 230$ (4.09), 312 (3.99) nm; IR (KBr) $v_{\max }$ $3423,2925,1704,1628,1608,1513,1459,1399,1275,1252$, $1159,1046 \mathrm{~cm}^{-1}$; ${ }^{1} \mathrm{H}$ - and ${ }^{13} \mathrm{C}-\mathrm{NMR}$ data, see Table 1; HR-ESIMS $m / z 623.3705[\mathrm{M}+\mathrm{Na}]^{+}$(Calcd for $\mathrm{C}_{39} \mathrm{H}_{52} \mathrm{O}_{5} \mathrm{Na}, 623.3707$ ).

21-(E)-Feruloyloxy-5 $\alpha$-cycloart-24-ene-3,23-dione

White, amorphous powder; $[\alpha]_{\mathrm{D}}^{25}+38.1(c=0.11, \mathrm{MeCN})$; UV $(\mathrm{MeCN}) \lambda_{\max }(\log \varepsilon) 203$ (4.08), 235 (4.08), 323 (3.85) nm; IR $(\mathrm{KBr}) v_{\max } 3430,2972,2923,1703,1662,1629,1453,1399$, 1273, 1160, $1046 \mathrm{~cm}^{-1}$; ${ }^{1} \mathrm{H}-$ and ${ }^{13} \mathrm{C}-\mathrm{NMR}$ data, see Table 1; HR-ESI-MS m/z $631.3992[\mathrm{M}+\mathrm{H}]^{+}$(Calcd for $\mathrm{C}_{40} \mathrm{H}_{55} \mathrm{O}_{6}$, 631.3993).

Cytotoxicity Assay The experimental process of cytotoxicity assay was afforded in our previously published paper. ${ }^{18)}$

Nitric Oxide (NO) Production Bioassays The details of the NO production bioassays were provided in a previously published paper. ${ }^{19)} \mathrm{N}$-Monomethyl-L-arginine was used as a positive control, and all experiments were performed in three independent replicates.

Acknowledgments The research was financially supported by the Project of National Natural Science Foundation of China (21272275 and 81202899), the Priority Academic Program Development of Jiangsu Higher Education Institutions (PAPD), the Specialized Research Fund for the Doctoral Program of Higher Education of China (20120096130002), and the Youth Fund Project of Basic Research Program of Jiangsu Province (Natural Science Foundation, BK2012251).

\section{References}

1) Jiangsu New Medical College, "Dictionary of Chinese Crude Drugs," Shanghai Scientific \& Technologic Press, Shanghai, 1977, p. 1925.

2) Fang X., Di Y. T., Geng Z. L., Tan C. J., Guo J., Ning J., Hao X. J., Eur. J. Org. Chem., 2010, 1381-1387 (2010).

3) Inada A., Konishi M., Murata H., Nakanishi T., J. Nat. Prod., 57, 1446-1449 (1994).

4) Wang X. N., Fan C. Q., Yin S., Gan L. S., Yue J. M., Phytochemistry, 69, 1319-1327 (2008).

5) Geng Z. L., Fang X., Di Y. T., Zhang Q., Zeng Y., Shen Y. M., Hao X. J., Tetrahedron Lett., 50, 2132-2134 (2009).

6) Zhang H. P., Wu S. H., Shen Y. M., Ma Y. B., Wu D. G., Qi S. H., Luo X. D., Can. J. Chem., 81, 253-257 (2003).

7) Zhang Q., Di Y. T., He H. P., Fang X., Chen D. L., Yan X. H., Zhu F., Yang T. Q., Liu L. L., Hao X. J., J. Nat. Prod., 74, 152-157 (2011).

8) Najmuldeen I. A., Hadi A. H. A., Awang K., Mohamad K., Ketuly K. A., Mukhtar M. R., Chong S. L., Chan G., Nafiah M. A., Weng N. S., Shirota O., Hosoya T., Nugroho A. E., Morita H., J. Nat. 
Prod., 74, 1313-1317 (2011).

9) Pan J. Y., Chen S. L., Li M. Y., Li J., Yang M. H., Wu J., J. Nat. Prod., 73, 1672-1679 (2010).

10) Garcez F. R., Garcez W. S., Roque N. F., Castellano E. E., Zukerman-Schpector J., Phytochemistry, 55, 733-740 (2000).

11) Lin B. D., Chen H. D., Liu J., Zhang S., Wu Y., Dong L., Yue J. M., Phytochemistry, 71, 1596-1601 (2010).

12) Liu C. M., Wang H. X., Wei S. L., Gao K., J. Nat. Prod., 71, 789792 (2008).

13) Tuchinda P., Pompimon W., Reutrakul V., Pohmakotr M., Yoosook C., Kongyai N., Sophasan S., Sujarit K., Upathum S. E., Santisuk T.,
Tetrahedron, 58, 8073-8086 (2002).

14) Lago J. H. G., Roque N. F., Phytochemistry, 60, 329-332 (2002).

15) Achenbach H., Frey D., Phytochemistry, 31, 4263-4274 (1992).

16) Prawat U., Chairerk O., Lenthas R., Salae A. W., Tuntiwachwuttikul P., Phytochem. Lett., 6, 286-290 (2013).

17) Kuo Yu.-H., Chang C. I., Kuo Y. H., Phytochemistry, 46, 1135-1137 (1997).

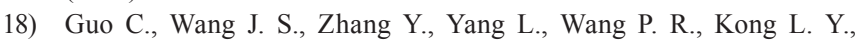
Chem. Pharm. Bull., 60, 1003-1010 (2012).

19) Yang M. H., Wang J. S., Luo J. G., Wang X. B., Kong L. Y., Bioorg. Med. Chem., 19, 1409-1417 (2011). 